\title{
US prepares ground for security clampdown
}

\section{Erika Check, Washington}

The United States is preparing draft guidelines to control the dissemination of a new category of 'sensitive homeland-security information', which could include blueprints of nuclear power plants or research on bioterrorism.

White House officials discussed the plans with representatives from scientific and academic communities on 22 August. But Kathryn Harrington, a spokeswoman for the Office of Science and Technology Policy (OSTP), says that an actual policy will not be released for several months.

Scientists have fretted since September that the government would take draconian action to restrict the publication of scientific information following last autumn's terrorist attacks. Although attendees of last week's meeting say that the administration's ideas on sensitive homeland-security information did not seem overly restrictive, they caution that they have yet to evaluate a specific proposal. Harrington says that this is because the proposal is still being developed by the Office of Management and Budget, at the request of Governor Tom Ridge, director of homeland security. The OSTP is helping the budget office with scientific aspects of the plan.

Some of those who attended the meeting say they are not opposed to the idea of the government taking formal steps to protect certain information. They add that they are pleased that the administration has included

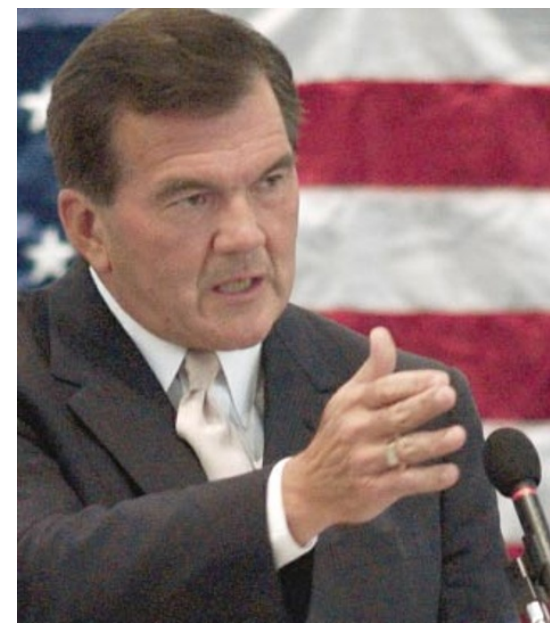

Under wraps: Tom Ridge is demanding fresh security guidelines for sensitive information.

them in early discussions. "It's much better for them and for us to have the chance to discuss things before the plane takes off," says Terry Hartle, a vice-president at the American Council on Education.

But Hartle and others are worried that they left the meeting with little clear idea of just what the administration considers to be sensitive homeland-security information.

"The community is very concerned about what information is going to be involved," says Janet Shoemaker, head of public affairs at the American Society for Microbiology. For instance, she says, the administration could take steps to protect 'dual-use' research, such as data on deadly pathogens. "There may be good reason to treat some information as a different category," she says, "but we don't want to restrict information that could lead to scientific advancement or medical benefits."

Some meeting participants say they got the impression that the policy will be aimed more at government-owned strategic information - such as plans of possible terrorist targets than at basic research done in the universities.

Attendees say that government officials seem to be interested in creating a new category of sensitive information primarily because it would be cheaper than fully classifying the information.

Participants also discussed the dilemmas that would accompany a new category of sensitive information, such as how it would be handled at scientific conferences. "Would you deny access to certain people at the meeting, or ask them to leave the room if it came up?" asks Rich Harpel of the National Association of State Universities and Land-Grant Colleges. "It was very unnerving to think about the way this might actually play itself out."

But computer-security expert David Farber of the University of Pennsylvania in Philadelphia — who didn't attend the meeting - says that researchers in his field often sign non-disclosure agreements with industry and that some meetings have long been closed to foreign researchers.

\section{Oceanographer navigates path to the Smithsonian}

\section{Kendall Powell, Washington}

After a couple of years of incessant bad news, researchers at the Smithsonian Institution were expressing some optimism this week following the appointment of a respected oceanographer as the museum complex's undersecretary of science.

Smithsonian secretary Larry Small -

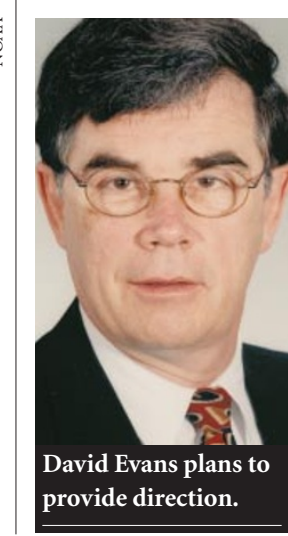
whose business-led approach has drawn him into bitter public conflict with many of the institution's researchers announced on 19 August that the position will be filled by David Evans, who is currently the senior research administrator at the National Oceanic and Atmospheric Administration.
Evans has a research background in physical oceanography and its interaction with climate. He succeeds Dennis O'Connor, who left the museum complex in May to become vice-president for research at the University of Maryland at College Park.

Researchers are now hoping that Evans can build a constructive relationship with the different branches of the sprawling Smithsonian empire. Scientists and other critics assailed Small last year for suggesting that the administration of the entire complex should be split in two, with research administered centrally and separately from exhibits. The director of the National Museum of Natural History resigned in protest at the plan (see Nature 411, 624; 2001), which is currently being reviewed by the Smithsonian Science Commission, a specially appointed scientific panel.

Evans says that he sees interaction between research and exhibition staff as a unique strength of the Smithsonian - the largest museum complex in the world.
"By using a combined facility of research and museum exposition, we can show people how science is really done," he says. But he asserts that some Smithsonian units have been "left adrift" by the institution, and says that he will draw on his experience to try to provide them with direction.

Institution staff say that they hope Evans's appointment and an ongoing search for a new director for the Natural History museum mean that the Smithsonian is heeding the science commission's call for the prompt hiring of strong scientific leaders. The commission's full report is due by the end of the year.

But some scientists remain sceptical that a central vision for the diverse Smithsonian science units will work. "We do a lot of different things for historical reasons," says Ira Rubinoff, director of the Smithsonian Tropical Research Institute in Panama. "The point is not that we do them all together, but whether it's good science that serves the nation — and I think it does." 